\title{
SSRI Augmentation by 5-Hydroxytryptophan Slow Release: Mouse Pharmacodynamic Proof of Concept
}

\author{
Jacob PR Jacobsen', Meghan L Rudder', Wendy Roberts', Elizabeth L Royer', Taylor J Robinson', \\ Adrianna Oh', Ivan Spasojevic ${ }^{2}$, Benjamin D Sachs' and Marc G Caron ${ }^{*, 1,2,3}$ \\ 'Department of Cell Biology, Duke University, Durham, NC, USA; ${ }^{2}$ Department of Medicine, Duke University, Durham, NC, USA; ${ }^{3}$ Department of \\ Neurobiology, Duke University Medical Center, Durham, NC, USA
}

\begin{abstract}
Drugs, notably SSRIs, that elevate brain extracellular 5-HT $\left(5-\mathrm{HT}_{\mathrm{Ext}}\right)$ are antidepressants. Unfortunately, most patients fail to remit. Multipronged clinical evidence suggests that elevating 5-HT Ext beyond the SSRI effect enhances antidepressant efficacy, but previous such drug strategies had prohibitive limitations. In humans, adjunct treatment with the 5-HT precursor 5-hydroxytryptophan (5-HTP) elevates 5-HT Ext beyond the SSRI effect. Small pilot trials suggest that adjunct 5-HTP can confer antidepressant response in treatment-resistant depression (TRD). However, sustained, stable 5- $\mathrm{HT}_{\text {Ext }}$ elevation is required for antidepressant effect; therefore, the rapid absorption and elimination of standard 5-HTP immediate release (IR) likely curtail 5-HTP IR's antidepressant potential. Slow-release (SR) drug delivery can crucially improve efficacy and safety of rapidly absorbed and eliminated compounds. Here we tested in mice the hypothesis that SR delivery will substantially improve 5-HTP's drug properties, by minimizing adverse effects and securing sustained $5-H T_{\text {Ext }}$ elevation beyond the SSRI effect. We modeled 5-HTP SR with minipumps, 5-HTP IR with injections, and chronic SSRI with dietary fluoxetine. We tested adjunct 5-HTP SR in wild-type mice and in mice with low brain 5-HT owing to expression of a mutant form of the brain 5-HT synthesis enzyme, tryptophan hydroxylase 2. In both lines of mice, adjunct 5-HTP SR synergized with SSRI to elevate 5-HT Ext beyond the SSRI effect. We observed no adverse effect. Adjunct 5-HTP IR could not produce this therapy-like profile, producing transient 5-HT Ext spikes and marked adverse effects. Integrated with a body of clinical data, our mouse data suggest that an adjunct 5-HTP SR drug could safely and effectively elevate 5-HT Ext beyond the SSRI effect and represent a novel treatment for TRD.
\end{abstract}

Neuropsychopharmacology (2016) 4I, 2324-2334; doi:I 0.1038/npp.2016.35; published online 30 March 2016

\section{INTRODUCTION}

First-line antidepressants, the selective serotonin reuptake inhibitors (SSRIs), are believed to work by causing sustained elevation of brain extracellular 5-hydroxytryptamine $\left(5-\mathrm{HT}_{\mathrm{Ext}}\right)$, by blocking the serotonin transporter (SERT) (Daws, 2009). But most patients do not remit (Trivedi et al, 2006). Adjunct atypical antipsychotics treat SSRI treatmentresistant depression (TRD), but only with modest efficacy (Mischoulon et al, 2014). Although drugs targeting the NMDA receptor hold promise (Aan Het Rot et al, 2012), TRD remains an urgent unmet medical need.

The SERT is but one of the several regulators of $5-\mathrm{HT}_{\mathrm{Ext}}$ (Celada et al, 2013; Daws, 2009; Sharp et al, 2007; Uutela et al, 2009). Selectively blocking the SERT might not always elevate $5-\mathrm{HT}_{\mathrm{Ext}}$ enough to elicit maximal antidepressant response. Indeed, clinical evidence suggests that elevating $5-\mathrm{HT}_{\mathrm{Ext}}$ beyond the effect of SERT blockade-by adjunct treatment with a second 5-HTergic drug-augments

* Correspondence: Dr MG Caron, Department of Neurobiology, Duke University Medical Center, Room 0487, CARL Building, Box 3287 , Durham, NC 277I0, USA. Tel: +| 919684 5433, Fax: +| $91968 \mid$ 864I,E-mail: marc.caron@dm.duke.edu

Received 14 December 2015; revised 22 February 2016; accepted 25 February 2016; accepted article preview online 2 March 2016 antidepressant efficacy. Unfortunately, previous adjunct drug strategies had limitations, related to mechanism, safety, or pharmacokinetics. Adjunct monoamine oxidase inhibitors are reported effective in TRD (Ebert et al, 1995) but can elicit severe adverse events (Hawley et al, 1996). Adjunct tryptophan is reported effective in TRD (Walinder et al, 1976), but tryptophan's half-life is short, $2 \mathrm{~h}$ (Green et al, 1980), and only a fraction of tryptophan is metabolized to 5-HT (Bender, 1983). Adjunct 5-hydroxytryptophan (5-HTP), the immediate 5-HT precursor, is reported effective in TRD (Nardini et al, 1983; van Praag, 1982), but 5-HTP's half-life, $2 \mathrm{~h}$, is short (Gijsman et al, 2002). Adjunct pindolol, by antagonizing $5-\mathrm{HT}_{1 \mathrm{~A}}$ inhibitory autoreceptors, enhances $5-\mathrm{HT}_{\mathrm{Ext}}$ elevation early in treatment and accelerates antidepressant onset (Whale et al, 2010). But chronic SSRI downregulates 5- $\mathrm{HT}_{1 \mathrm{~A}}$ autoreceptors (Hensler, 2003), which likely explains why adjunct pindolol is little effective in TRD (Whale et al, 2010). Further, adjunct methylfolate to SSRIs is reported to be effective in TRD (Papakostas et al, 2012), via a mechanism believed to involve augmented 5-HT synthesis and neurotransmission (Stahl, 2008). Thus, our overall therapeutic hypothesis is that an adjunct drug that safely and in a sustained manner elevates $5-\mathrm{HT}_{\mathrm{Ext}}$ beyond the SSRI effect will be effective in TRD.

In humans, as assessed indirectly using plasma hormone biomarkers, and in animals, acute adjunct 5-HTP 
synergistically augments the $5-\mathrm{HT}_{\text {Ext }}$-elevating effect of an SSRI (Lowe et al, 2006; Perry and Fuller, 1993). As mentioned, small double-blind trials report that adjunct 5-HTP confers efficacy in TRD to a SERT inhibitor (Nardini et al, 1983; van Praag, 1982). Such trials are not conclusive, but similar pilot trials also provided initial evidence of antidepressant efficacy of tricyclic antidepressants and ketamine (Berman et al, 2000; Lopez-Munoz and Alamo, 2009). The preliminary clinical evidence for antidepressant augmentation by adjunct 5-HTP is intriguing. However, the $2 \mathrm{~h}$ half-life of standard 5-HTP immediate release (IR), unless dosed very frequently, entails highly fluctuating and intermittent 5-HTP exposure (Gijsman et al, 2002), which likely limits 5-HTP's therapeutic potential. To minimize risk of relapse and withdrawal, 5-HTergic antidepressant action mandates sustained $5-\mathrm{HT}_{\mathrm{Ext}}$ elevation and infrequent dosing (Delgado, 2006). 5-HTP has never been associated with serious adverse events in humans (NIH TOXNET and Turner et al, 2006). However, 5-HTP can cause rapid gastrointestinal adverse events, presumably due to rapid 5-HT spikes upon dosing (Lowe et al, 2006). For fasteliminated compounds, advanced slow-release (SR) formulations can reduce dose frequency, minimize adverse effects, and stabilize and maximize drug exposure, thereby increasing overall clinical effectiveness (Thombre, 2005). Thus, our pharmacology hypothesis is that adjunct 5-HTP SR will safely and in a sustained manner elevate $5-\mathrm{HT}_{\text {Ext }}$ beyond the SSRI effect. If so, an adjunct 5-HTP SR drug could be effective in TRD.

Here we tested our pharmacology hypothesis in mice. The limited predictive value of animal 'antidepressant-like' behavioral models has hampered antidepressant research (Insel, 2012). Antidepressant-like behavioral models have a track record of false positives and negatives (Benton et al, 2012; Griebel et al, 2002), may classify antidepressants as pro-depressants (Benton et al, 2012), and pro-depressants as antidepressant (Griebel et al, 2005). Instead, our approach was inspired by a National Institute of Health initiative that bypasses behavioral models and instead uses pharmacodynamic end points plausibly predicting antidepressant efficacy (NIMH, 2012). Here our primary pharmacodynamic end points were (a) brain $5-\mathrm{HT}_{\text {Ext }}$ as a plausible translational biomarker of antidepressant treatment augmentation and (b) exploratory toxicology. Comparison to 5-HTP IR, 5-HT tissue storage, plasma 5-HTP, 5-HTP SR oral bioavailability, and 5-HTP intestinal absorption were secondary end points. Our working hypothesis was that, as compared with 5-HTP IR, 5-HTP SR would allow for higher 5-HTP doses, produce sustained $5-\mathrm{HT}_{\text {Ext }}$ elevation beyond the maximal SSRI effect, and minimize adverse events. We tested adjunct 5-HTP SR under normal and 5-HT-deficient conditions.

\section{MATERIALS AND METHODS}

\section{Animals}

Mice were housed 3-5/cage with food and water available ad libitum on a 12-h light-dark cycle at $21 \pm 1^{\circ} \mathrm{C}$. All experiments used female age-matched littermate wild-type (WT) and tryptophan hydroxylase $2^{\mathrm{Arg}} 439^{\mathrm{His}}$ knock-in mice (3-6-month old), bred from heterozygous crosses and maintained on a mixed $129 \mathrm{~S} 6 / \mathrm{SvEv} \times \mathrm{C} 57 \mathrm{BL} / 6 \mathrm{~J}$ background, as described (Beaulieu et al, 2008). The tryptophan hydroxylase $2{ }^{\mathrm{Arg}} 439^{\mathrm{His}}$ knock-in mice, henceforth referred

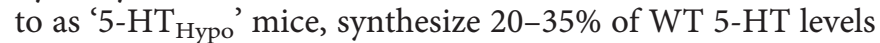
(Beaulieu et al, 2008; Jacobsen et al, 2012b) and were used here as a naturalistic model of 5-HT deficiency. Female mice only were used because of smaller and less varying size, allowing for higher 5-HTP SR dose, given fixed minipump capacity (see below). Experiments were conducted in accordance with the National Institutes of Health guidelines for the care and use of animals and an approved protocol from the Duke University Animal Care and Use Committee.

\section{Materials}

Fluoxetine $\mathrm{HCl}$ was purchased from Sequoia Research Products (Pangbourne, UK). 5-HTP was purchased from EMD Millipore (Billerica, MA). 5-HT, 5-hydroxyindoleacetic acid (5-HIAA), saccharin, and phenol red solution $(0.5 \%$ in Dulbecco's buffer) were purchased from Sigma (St Louis, MO, USA). All chemicals were of analytical grade.

\section{Drug Treatments}

Chronic SSRI treatment was modeled by fluoxetine in the drinking water $(\sim 20 \mathrm{mg} / \mathrm{kg} /$ day $)$. This regimen produces fluoxetine plasma levels at $\sim 1500 \mathrm{ng} / \mathrm{ml}$, above clinical levels, and was used here to ensure maximal SERT occupancy (Siesser et al, 2013). Adjunct 5-HTP SR (100 mg/kg/day) for 5 days was modeled using s.c. osmotic minipumps. Given pump capacity and 5-HTP solubility, $100 \mathrm{mg} / \mathrm{kg} /$ day was the highest dose possible. In one experimental design, we modeled 5-HTP SR via 5-HTP in the drinking water ( $300 \mathrm{mg} / \mathrm{kg} / \mathrm{day}$, highest dose mice would ingest) for 3 weeks. Adjunct 5-HTP IR was modeled by twice daily (AM and $\mathrm{PM}$ ) s.c. injections (3.125-50 mg/kg/injection). See Supplementary Methods for details.

\section{Microdialysis for Frontal Cortex $5-\mathrm{HT}_{\mathrm{Ext}}$}

Microdialysis for $5-\mathrm{HT}_{\text {Ext }}$ was performed in awake mice essentially as described (Jacobsen et al, 2012b). Assessment was carried out after 5 days $(120 \mathrm{~h})$ of adjunct 5 -HTP SR or IR treatment. In 5-HTP SR-treated mice, 5- $\mathrm{HT}_{\mathrm{Ext}}$ was assessed at 10 AM. In 5-HTP IR-treated mice, 5-HT Ext $_{\text {was }}$ quantified in dialysates collected before and after the 10 AM injection. See Supplementary Methods for details.

\section{Tissue and Blood Samples}

Frontal cortex tissue samples for 5-HT and 5-HIAA analysis were prepared as described (Jacobsen et al, 2012b). Blood and plasma samples for 5-HT and 5-HTP analysis, respectively, were prepared from trunk or tail vein blood. See Supplementary Methods for details.

\section{Monoamine Analysis}

5-HT levels in dialysates, tissue, and in whole blood were quantified by high-performance liquid chromatography (HPLC) with electrochemical detection as described (Jacobsen et al, 2012b). For plasma 5-HTP, the mobile phase $\mathrm{pH}$ was $2-2.3$, to retain 5 -HTP on the column. 


\section{Exploratory Toxicology: Physiological Measures}

Diarrhea, tremor, hypothermia, and head twitches are commonly reported to occur in mice following high-dose 5-HTP adjunct to SSRI (Fox et al, 2008; Sanchez et al, 2003). Other typical 5-HT toxicity behaviors, such as backward movement, head-weaving, and hind-limb splaying (Fox et al, 2008; Sanchez et al, 2003), were not observed, and therefore not scored. All mice were treated with fluoxetine for 14 days before adjunct 5-HTP SR or IR. In adjunct 5-HTP IR-treated mice, all parameters were assessed starting $15 \mathrm{~min}$ after the AM injection on days 1-4. In adjunct 5-HTP SR-treated mice, assessment was carried out repeatedly the day of minipump implantation and daily on days $2-4$. See Supplementary Methods for details.

\section{Exploratory Toxicology: Behavioral Measures}

All mice were treated with fluoxetine for 14 days before adjunct 5-HTP SR. Spontaneous activity in a novel environment was assessed at days 2 and 5 after the 5-HTP SR minipump implantation. Motor strength and coordination were assessed at day 3 on an accelerating rotorod. See Supplementary Methods for details.

\section{5-HTP Plasma $_{\text {after 5-HTP IR }}$}

Mice treated with fluoxetine for 2 weeks were injected with 5-HTP IR 3.125 or $6.25 \mathrm{mg} / \mathrm{kg}$. Tail blood samples were collected at 0 (baseline), 5, 10, 15, 20,30, and 45 min by nicking the tail and collecting blood into $20 \mu \mathrm{l}$ EDTA-coated capillaries (Sarstedt, Newton, NC). 5-HTP Plasma was determined by HPLC.

\section{Intestinal Absorption}

5-HTP absorption in the jejunum and colon were assessed using the ligated loop model. In brief, the mouse was anesthetized, the intestine accessed via an incision in the abdomen, and a segment ligated. In all mice, $10 \mathrm{mg} / \mathrm{kg}$ 5-HTP (or phenol red, as poorly absorbed marker) was injected into the intestinal lumen in a volume of $50 \mu \mathrm{l}$ and plasma concentrations of 5-HTP (or phenol red) were monitored for $120 \mathrm{~min}$. See Supplementary Methods for details.

\section{Statistical Analysis}

Data were analyzed with unpaired Student's $t$-test, two-way analysis of variance (ANOVA), or two-way repeated-measures (RM) ANOVA using the Prism statistical software version 5.0f (GraphPad Software, La Jolla, CA, USA). When significant factor effects or factor interactions were detected, ANOVA was followed by Bonferroni's or Dunnett's post-hoc analysis. Our focus was the effect of adjunct 5-HTP SR, not tph2 genotype, and $\mathrm{WT}$ and $5-\mathrm{HT}_{\mathrm{Hypo}}$ data were analyzed separately. Data are presented as mean \pm SEM. Additional statistical information is available in Supplementary Table S1.

\section{RESULTS}

Adjunct 5-HTP SR Elevates 5-HT $\mathrm{Ext}_{\text {Ext }}$ Beyond the Maximal SSRI Effect

To model both the normal and 5-HT-deficient condition, we investigated 5-HTP SR in WT and 5- $\mathrm{HT}_{\text {Hypo }}$ mice (Beaulieu et al, 2008; Jacobsen et al, 2012b). We modeled chronic highdose SSRI by administering $\sim 20 \mathrm{mg} / \mathrm{kg} /$ day fluoxetine for 14 days. This abolished SERT binding of the radioligand, suggesting $100 \%$ SERT occupancy (Supplementary Figure S1), although downregulation of SERT could partly explain the finding (Hirano et al, 2005). This finding excludes the possibility that additional $5-\mathrm{HT}_{\mathrm{Ext}}$ elevation consequent to adjunct 5-HTP SR only compensated for incomplete SERT occupancy. Unless noted, we modeled zero-order 5-HTP SR for 5 days using osmotic minipumps (Figure 1a).

As reported (Jacobsen et al, 2012b), 5- $\mathrm{HT}_{\text {Hypo }}$ mouse baseline dialysate $5-\mathrm{HT}_{\text {Ext }}$ levels $(58.5 \pm 6.2 \mathrm{pM})$ were $25 \%$ of WT $(236 \pm 29 \mathrm{pM})$ (Figure 1b). In WT mice, fluoxetine and 5 -HTP SR alone increased dialysate $5-\mathrm{HT}_{\mathrm{Ext}}$ by $600 \%$ (to $1760 \pm 152 \mathrm{pM}$ ) and by $60 \%$ (to $386 \pm 34 \mathrm{pM}$ ), respectively (Figure 1c). Adjunct 5-HTP SR synergized with fluoxetine in WT mice, elevating dialysate $5-\mathrm{HT}_{\mathrm{Ext}}$ by $1100 \%$ (to $2842 \pm 221 \mathrm{pM}$ ), beyond the sum of each treatment's own effect. In 5-HT $\mathrm{H}_{\mathrm{Hypo}}$ mice, fluoxetine alone increased dialysate $5-\mathrm{HT}_{\mathrm{Ext}}$ only slightly (to $67 \pm 12 \mathrm{pM}$ ) and non-significantly (Figure $1 \mathrm{~b}$ and $\mathrm{c}$ ). In contrast, 5-HTP SR alone increased dialysate $5-\mathrm{HT}_{\mathrm{Ext}}$ by $400 \%$ in $5-\mathrm{HT}_{\mathrm{Hypo}}$ mice (to $295 \pm 60 \mathrm{pM}$ ), a dialysate $5-\mathrm{HT}_{\mathrm{Ext}}$ concentration increase numerically similar to that in WT mice. As in WT mice, in 5- $\mathrm{HT}_{\text {Hypo }}$ mice adjunct 5-HTP SR synergized with fluoxetine to elevated dialysate $5-\mathrm{HT}_{\mathrm{Ex}}$, by $900 \%$ (to $555 \pm 68 \mathrm{pM}$ ), again beyond the sum of each treatment's own effect.

When examining $5-\mathrm{HT}_{\text {Tissue }}$, ie, neuronal $5-\mathrm{HT}$ storage, we found that fluoxetine depleted $5-\mathrm{HT}_{\text {Tissue }}$ by $90 \%$ in $5-\mathrm{HT}_{\text {Hypo }}$ mice, as previously observed (Siesser et al, 2013). Adjunct 5-HTP SR counteracted the 5- $\mathrm{HT}_{\text {Tissue }}$ depletion in fluoxetine-treated 5- $\mathrm{HT}_{\text {Hypo }}$ mice. When given alone, 5-HTP $\mathrm{SR}$ restored the $5-\mathrm{HT}_{\text {Tissue }}$ levels of $5-\mathrm{HT}_{\text {Hypo }}$ mice to $>50 \%$ of WT. None of the treatments significantly altered $5-\mathrm{HT}_{\text {Tissue }}$ levels in WT mice (Figure 1d), indicating that neuronal 5-HT storage in WT mice at baseline is close to capacity.

To estimate the 5-HTP exposure corresponding to augmented brain $5-\mathrm{HT}_{\mathrm{Ext}}$, we quantified 5 - $\mathrm{HTP}_{\text {Plasma }}$ levels after 5-HTP SR treatment. The 5-HTP $\mathrm{Plasma}_{\text {levels, }}$ $\sim 1200 \mathrm{ng} / \mathrm{ml}$, were moderate (Figure 1e) and close to the therapeutic levels for some antidepressants (Baumann et al, 2005). Fluoxetine decreased while 5-HTP SR increased whole blood levels of 5-HT. Fluoxetine and 5-HTP SR combined cancelled out each treatment's effect (Supplementary Figure S2).

To determine whether 5-HTP could be administered in a SR-like mode orally, we treated mice with 5-HTP in the drinking water for 14 days, $\sim 300 \mathrm{mg} / \mathrm{kg} /$ day, without fluoxetine. Oral 5-HTP SR increased 5-HT Tissue to a similar extent as minipump 5-HTP SR (Figure 1f) and did not change noradrenaline, dopamine, or dopamine metabolites in the frontal cortex or hippocampus (Supplementary Figure S3). Oral 5-HTP SR caused no obvious adverse effects (Supplementary Figure S4).

\section{Adjunct 5-HTP SR to Chronic SSRI Treatment Causes No Adverse Events}

In rodents, acute high doses of 5-HTP IR combined with an SSRI cause physiological adverse effect, including diarrhea, 
a

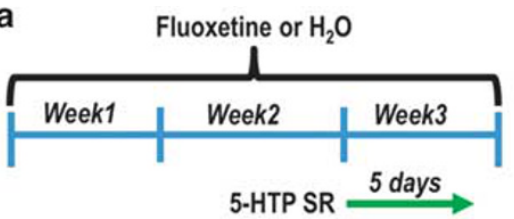

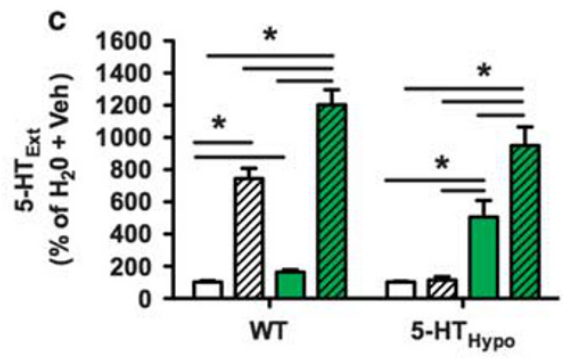

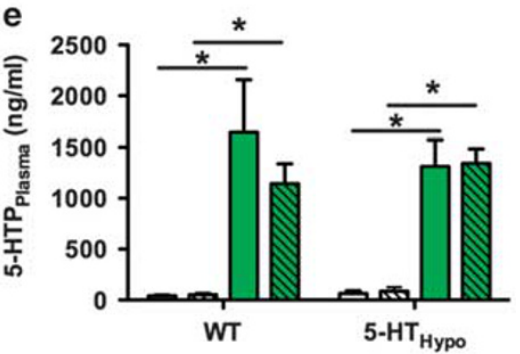

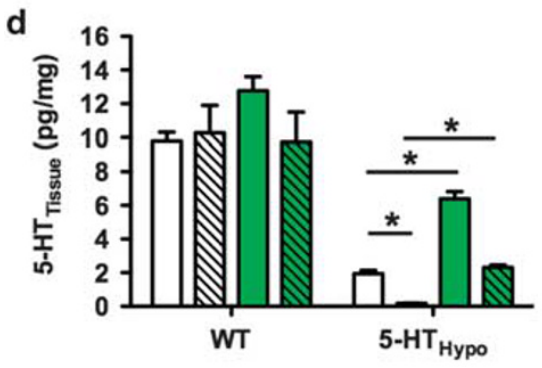

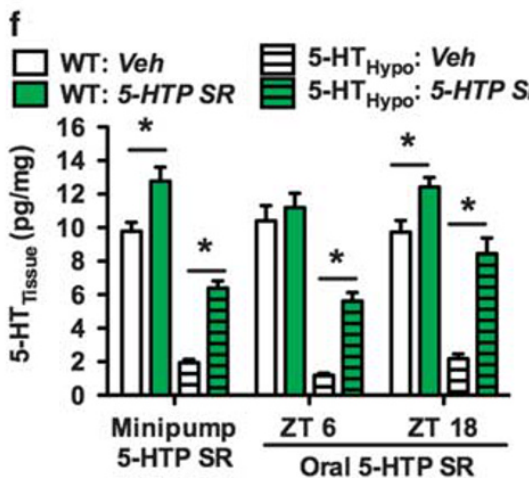

Figure I 5-HTP SR elevates 5-HT Ext beyond the effect of SSRI treatment alone. (a) Treatment schematic for (b-e). Mice were treated for I4 days with fluoxetine $(20 \mathrm{mg} / \mathrm{kg} /$ day $)$. Here after, minipumps delivering 5 -HTP SR ( $100 \mathrm{mg} / \mathrm{kg} /$ day $)$ or vehicle were implanted. All assessments were carried out 5 days (I $20 \mathrm{~h})$ after minipump implantation. (b) Frontal cortex 5-HT Ext $(\mathrm{N}=5-25)$ in absolute values, (c) frontal cortex 5-HT Ext $(N=5-25)$ percentage of values normalized to untreated controls, (d) frontal cortex 5-HTTissue $(\mathrm{N}=4-6)$, and (e) 5-HTP Plasma $(\mathrm{N}=4-5)$ following treatment with fluoxetine, 5-HTP SR via minipumps, or the combination. (f) Effect of 5 -HTP SR via minipumps ( $100 \mathrm{mg} / \mathrm{kg} /$ day, 5 days) or the drinking water (300 mg/kg/day) on frontal cortex 5-HT Tissue $(\mathrm{N}=4-13)$ in mice not treated with fluoxetine. ZT = zeitgeber time, ie, hours after lights on on a 12-h: I2-h light-dark cycle. Data represent means \pm SEM. WT and 5-HTHypo mice were analyzed separately. (b-e) Two-way ANOVA followed by Bonferroni's post-hoc test. (f) Student's t-test. * $p<0.05$. Additional statistical information is available in Supplementary Table SI.

tremor, head twitches, and hypothermia (Sanchez et al, 2003). We monitored WT and 5- $\mathrm{HT}_{\mathrm{Hypo}}$ mice on fluoxetine for $8 \mathrm{~h}$ immediately after 5 -HTP SR minipump implantation (Figure $2 \mathrm{~b}$ and $\mathrm{c}$ ) and thereafter daily for 3 days (Figure $2 \mathrm{~d}-\mathrm{f}$ ). We observed no diarrhea, tremor, or hypothermia at any time point. In a separate set of mice, we assessed spontaneous activity in a novel cage $24 \mathrm{~h}$ after 5-HTP SR minipump implantation (day 2), coordination and motor strength on an accelerating rotorod after $48 \mathrm{~h}$ (day 3), and spontaneous activity, rearing, and anxiety in activity monitors after $120 \mathrm{~h}$ (day 6). Body weights were monitored throughout the treatment. Again, we observed no adverse effects of adjunct 5-HTP SR (Figure 3b-h).

\section{Adjunct 5-HTP IR to Chronic SSRI Treatment Causes Pronounced Adverse Effect}

We administered adjunct 5-HTP as IR over 4 days, dividing the $100 \mathrm{mg} / \mathrm{kg} / \mathrm{day}$ dose into two daily $50 \mathrm{mg} / \mathrm{kg}$ s.c. injections (AM and $\mathrm{PM}$ ). In striking contrast to adjunct 5-HTP SR, upon each dosing adjunct 5-HTP IR caused pronounced diarrhea, tremor, and hypothermia, as well as head twitches. These adverse events did not abate over 4 days of treatment and was apparent in both WT and $5-\mathrm{HT}_{\mathrm{Hypo}}$ mice (Figure $4 \mathrm{~b}-\mathrm{e}$ ). To determine the maximally tolerated adjunct 5-HTP IR dose in our model system, we titrated down the 5-HTP IR dose (twice 

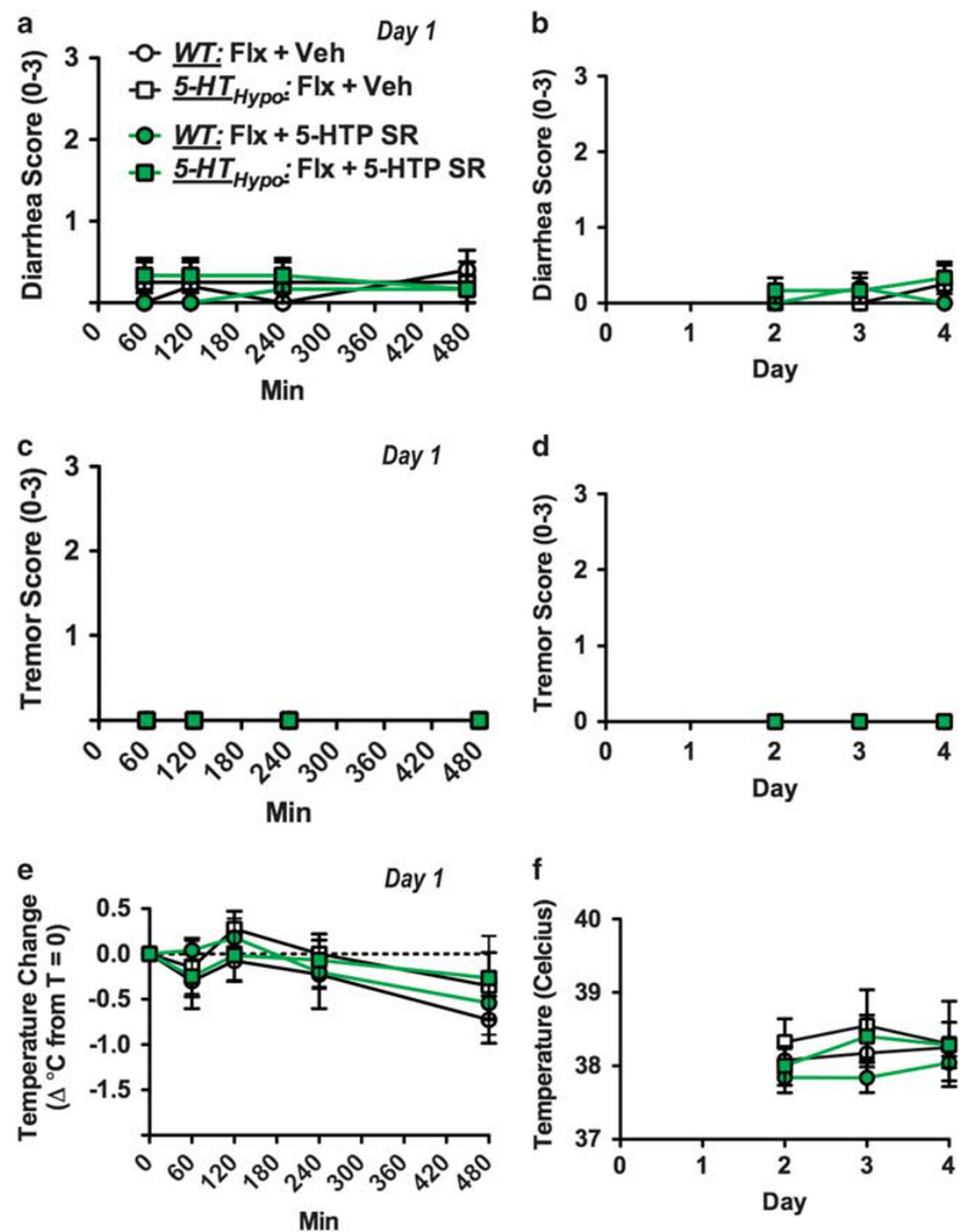

Figure 2 Absence of physiological adverse events following adjunct 5-HTP SR to chronic SSRI treatment. (a, c, e) Mice were assessed at multiple time points immediately following implantation (day I) and (b, d, f) daily on the 3 subsequent days (day 2-4). 5-HTP SR did not cause diarrhea, tremor, or hypothermia at any time point. Paradigm as outlined in Figure la, except that all mice were fluoxetine treated. Data represent means \pm SEM (N=4-5). WT and 5- $\mathrm{HT}_{\text {Hypo }}$ mice were analyzed separately. (a-f) Two-way repeated-measures ANOVA followed by Bonferroni's post-hoc test. Additional statistical information is available in Supplementary Table SI.

daily $25,12.5,6.25,3.125 \mathrm{mg} / \mathrm{kg} /$ injection). Even at twicedaily adjunct $3.125 \mathrm{mg} / \mathrm{kg} /$ injection $\quad(6.25 \mathrm{mg} / \mathrm{kg} /$ day $)$ 5-HTP IR still caused moderate diarrhea in $5-\mathrm{HT}_{\text {Hypo }}$ mice (Figure 4f).

Thus, in our model system, the maximal tolerated dose for adjunct 5 -HTP SR was $\geqslant 100 \mathrm{mg} / \mathrm{kg} /$ day, at least 16 times higher than for adjunct 5-HTP IR, $\leqslant 6.25 \mathrm{mg} /$ $\mathrm{kg} /$ day.

Adjunct 5-HTP IR (3.125 or $6.25 \mathrm{mg} / \mathrm{kg} /$ injection) produced a rapid rise in $5-\mathrm{HTP}_{\text {Plasma }}$, which peaked at $10 \mathrm{~min}$, and largely returned to baseline at $45 \mathrm{~min}$ (Figure 4i). Intriguingly, the peak $5-\mathrm{HTP}_{\text {Plasma }}$ levels produced by the subtoxic $3.125 \mathrm{mg} / \mathrm{kg} /$ injection 5-HTP IR dose were, at $\sim 800 \mathrm{ng} / \mathrm{ml}$, below the levels $(\sim 1200 \mathrm{ng} / \mathrm{ml})$ observed after adjunct 5-HTP SR in minipumps. This indicates that higher

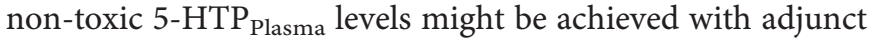
5-HTP SR vs 5-HTP IR.
Sub-Toxic Adjunct 5-HTP IR is Ineffective in Elevating Brain 5-HT $\mathrm{H}_{\text {Ext }}$ Beyond the SSRI Effect

Next we studied the effect of adjunct 5-HTP IR on dialysate $5-\mathrm{HT}_{\text {Ext }}$. Adjunct $50 \mathrm{mg} / \mathrm{kg}$ 5-HTP IR produced large dialysate $5-\mathrm{HT}_{\mathrm{Ext}}$ spikes in both WT and $5-\mathrm{HT}_{\mathrm{Hypo}}$ mice, likely explaining the marked adverse effects at this dose. Adjunct $3.125 \mathrm{mg} / \mathrm{kg} 5$-HTP IR only increased dialysate $5-\mathrm{HT}_{\text {Ext }}$ transiently and only in $5-\mathrm{HT}_{\mathrm{Hypo}}$ mice (Figure $5 \mathrm{a}$ and $b$ ).

We also tested the capacity of 5-HTP IR to increase 5-HT tissue storage in mice not treated with fluoxetine. Only the toxic $50 \mathrm{mg} / \mathrm{kg} 5-\mathrm{HTP}$ IR dose substantially increased $5-\mathrm{HT}_{\text {Tissue }}$ at $8 \mathrm{~h}$ after administration on day 5 and only in $5-\mathrm{HT}_{\text {Hypo }}$ mice. The subtoxic $3.125 \mathrm{mg} / \mathrm{kg} 5-\mathrm{HTP}$ IR dose was ineffective in WT and increased $5-\mathrm{HT}_{\text {Tissue }}$ modestly in $5-\mathrm{HT}_{\text {Hypo }}$ mice (Figure $5 \mathrm{c}$ and $\mathrm{d}$ ). 

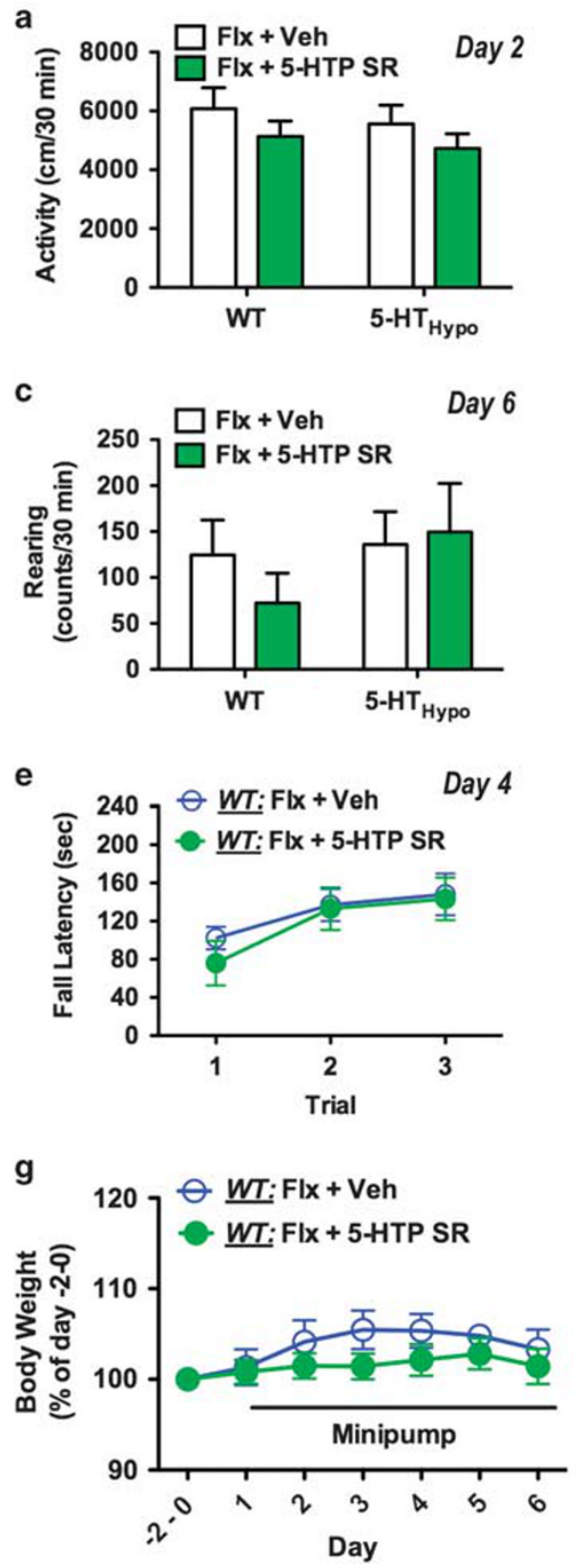

b
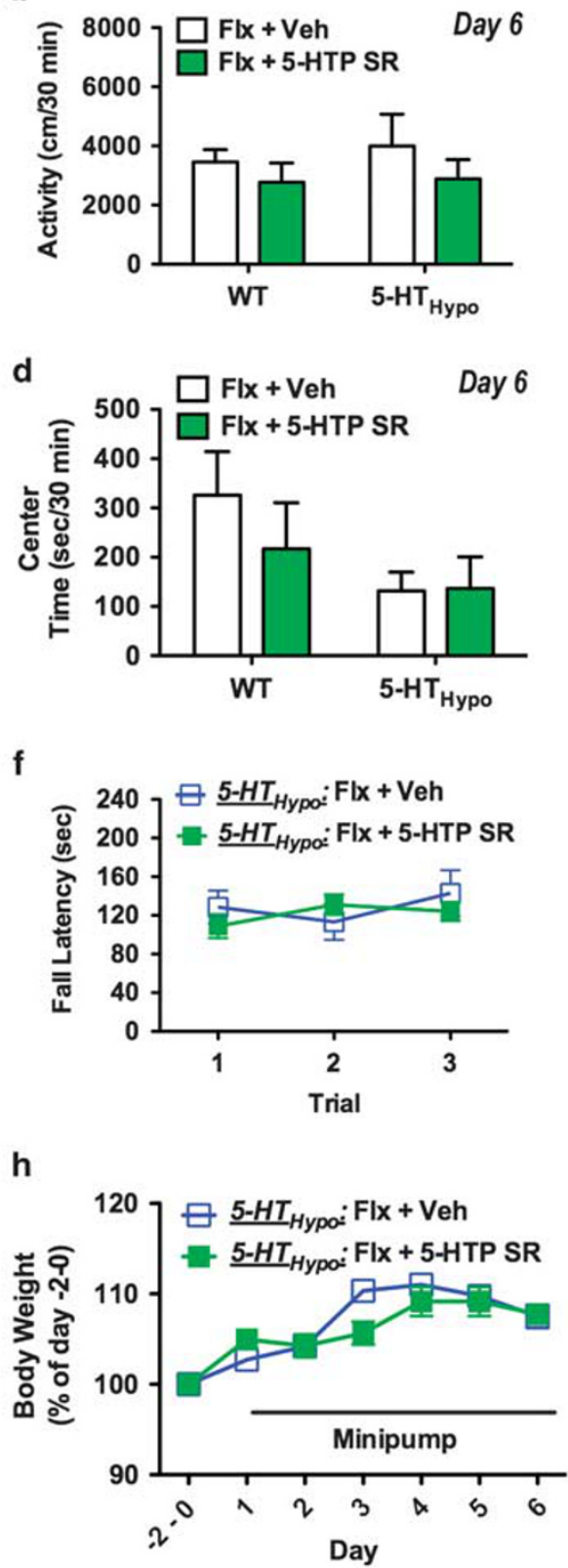

Figure 3 Absence of behavioral adverse events and weight loss following adjunct 5-HTP SR to chronic SSRI treatment. (a) No change in spontaneous forward activity in a novel cage on day 2. No change in spontaneous (b) forward activity, (c) rearing activity, and (d) center time in locomotor chambers on day 6. (e, f) No motor strength or coordination deficits on an accelerating rotorod on day 3. (g, h) No significant effect on body weight during 5 days of adjunct 5-HTP SR treatment. Paradigm as outlined in Figure la, except that all mice were fluoxetine treated. Data represent means \pm SEM ( $N=6-7)$. WT and 5$\mathrm{HT}_{\text {Hypo }}$ mice were analyzed separately. (a-d) Student's t-test. (e-h) Two-way repeated-measures ANOVA followed by Bonferroni's post-hoc test. Additional statistical information is available in Supplementary Table SI.

\section{5-HTP is Absorbed by the Mouse Colon}

Good colonic absorption of a compound expands the range of SR technology options (Thombre, 2005). We therefore determined colon absorption of 5-HTP in vivo, relative to jejunum absorption, by injecting $10 \mathrm{mg} / \mathrm{kg} 5$ - HTP into the lumen of either the colon or jejunum. As deduced from

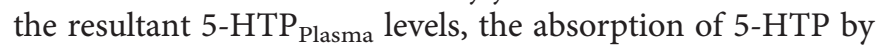
the jejunum and colon was roughly similar, with a delayed absorption profile in the colon (Figure 6a). Intestinal absorption studies normally include a 'poorly absorbed marker', such as phenol red, to control for absorption related to bulk flow or leaks. When we injected $10 \mathrm{mg} / \mathrm{kg}$ phenol red into the colon lumen, we detected little or no phenol red $_{\text {Plasma }}$ (Figure 6c). Injecting $10 \mathrm{mg} / \mathrm{kg}$ phenol red into the jejunum lumen produced phenol red Plasma levels similar to the $5-\mathrm{HTP}_{\text {Plasma }}$ levels we observed after $10 \mathrm{mg} / \mathrm{kg} 5-\mathrm{HTP}$ in this region. This does not mean 5-HTP and phenol red were absorbed equally in the jejunum. Phenol red is excreted mostly non-metabolized (Collado et al, 1988), whereas 
5-HTP is quickly metabolized to 5 - $\mathrm{HT}$ and subsequently 5-HIAA. Indeed, intraluminal 5-HTP injections resulted in 5-HIAA Plasma $_{\text {levels }} \sim 40$ times larger than the resultant $5-\mathrm{HTP}_{\text {Plasma }}$ levels (Figure $6 \mathrm{~b}$ ). This demonstrates that the $5-\mathrm{HTP}_{\text {Plasma }}$ detected represented a fraction of the 5-HTP actually absorbed. Further, after i.v. injection phenol red $_{\text {Plasma }}$ exposure were 3.5 times higher than for

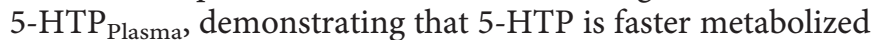
than phenol red (Supplementary Figure S5). We also measured the 5-HTP degradation rate in jejunum and colon
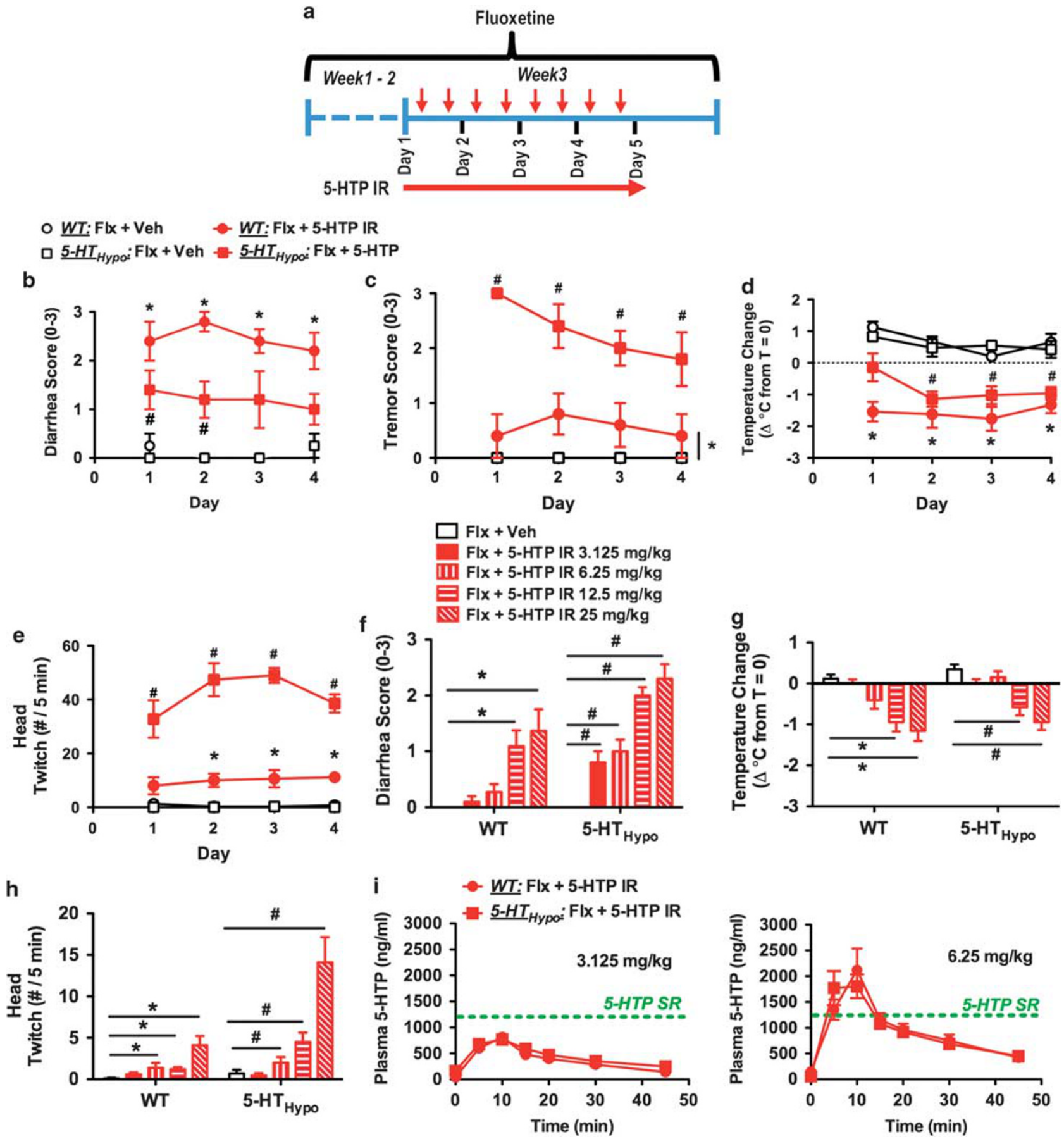

Figure 4 Adjunct 5-HTP IR to chronic SSRI treatment causes adverse events. (a) Treatment schematic for (b-h). Mice were treated for I4 days with fluoxetine $(20 \mathrm{mg} / \mathrm{kg} /$ day). Here after, twice-daily 5-HTP IR (AM and PM) was administered for 4 days. Assessments were carried out following AM administration, (b-e) daily for 4 days or (f-h) on day 4. (b-d) Adjunct 5-HTP IR $(2 \times 50 \mathrm{mg} / \mathrm{kg} /$ day) caused (b) diarrhea, (c) tremor, (d) hypothermia, and (e) head twitches in both WT and 5-HTHypo mice. $(\mathrm{N}=4-5)$. ( $\mathrm{f}-\mathrm{h})$ Assessment of descending doses of adjunct 5-HTP IR (2 $\times 3.125-25 \mathrm{mg} / \mathrm{kg} / \mathrm{day})$ for causing ( $f$ ) diarrhea, $(\mathrm{g})$ hypothermia, and $(\mathrm{h})$ head twitches. Even a 5-HTP IR dose as low as $3.125 \mathrm{mg} / \mathrm{kg}$ caused modest diarrhea in 5-HTHypo mice. $(\mathrm{N}=10-1 \mathrm{I})$. (i) $5-\mathrm{HTP}$ Plasma profile following $5-\mathrm{HTP}$ IR 3.125 or $6.25 \mathrm{mg} / \mathrm{kg}$. Green line represents the 5-HTP Plasma levels observed after 5-HTP SR in minipumps. $(N=9)$. Data represent means \pm SEM. (b-e) Two-way repeated-measures ANOVA or $(f-h)$ two-way ANOVA followed by Bonferroni's post-hoc test. ${ }^{*} p<0.05$, within WT mice. ${ }^{*} p<0.05$, within $5-\mathrm{HT}_{\text {Hypo }}$ mice. Additional statistical information is available in Supplementary Table SI. 

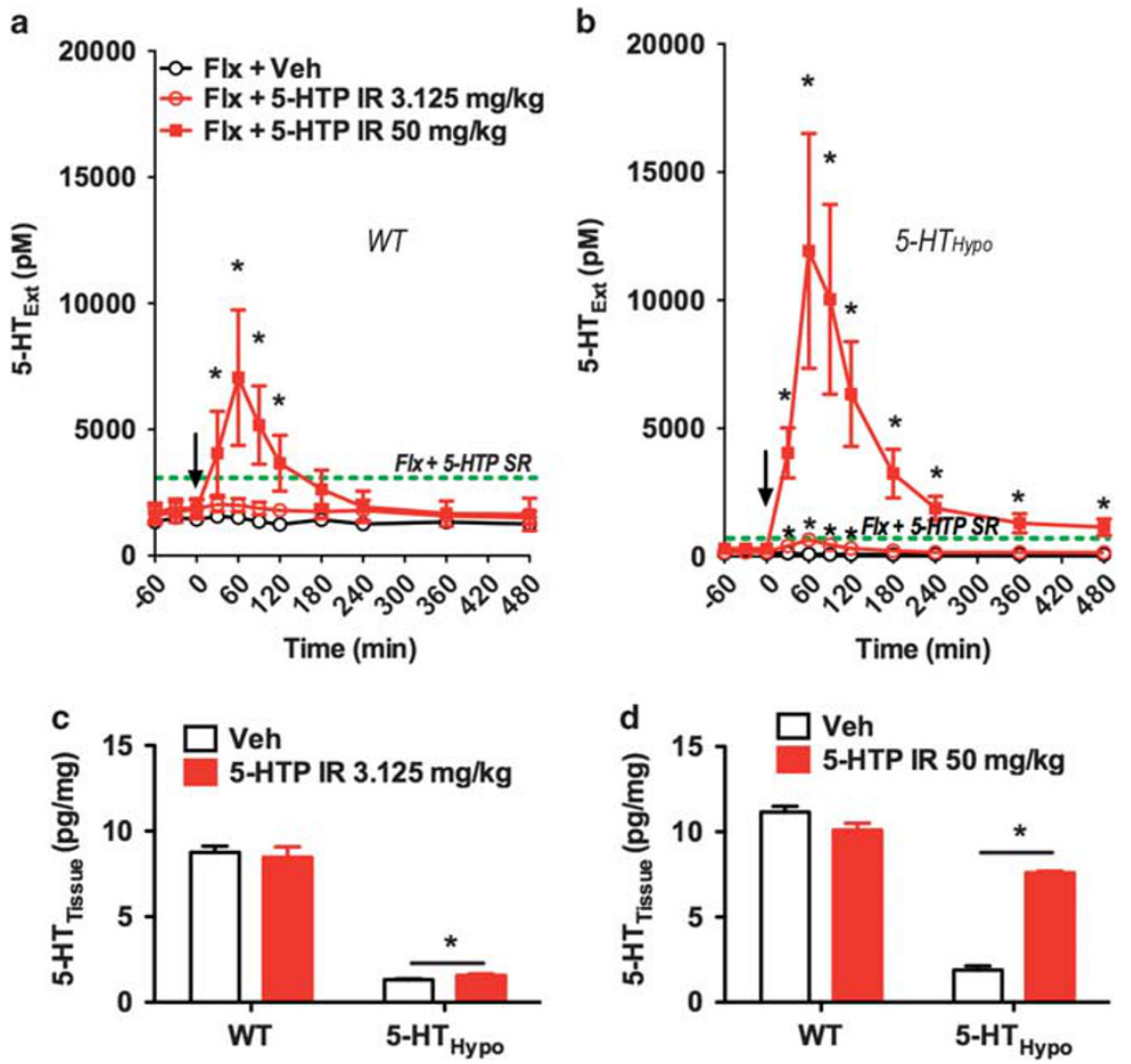

Figure 5 Subtoxic 5-HTP IR is inefficient in elevating 5-HT Ext beyond the SSRI effect. (a, b) Effect of adjunct 5-HTP IR on 5-HT Ext in SSRI-treated mice. Subtoxic 5-HTP IR $(3.125 \mathrm{mg} / \mathrm{kg})$ only transiently elevated 5-HT Ext upon dosing and only in 5-HT Hypo mice. $(\mathrm{N}=3-4)$. Dotted lines represent the levels observed after adjunct 5-HTP SR ( $100 \mathrm{mg} / \mathrm{kg} /$ day). As in Figure 4a, 5-HTP was injected twice daily over 5 days. 5-HT Ext was assessed at the first daily 5-HTP injection on the fifth day, $120 \mathrm{~h}$ after the initial injection. (c, d) Effect of adjunct 5-HTP IR on 5-HTTissue assessed $8 \mathrm{~h}$ postinjection after the last AM injection after 5 days of twice-daily treatment in mice not treated with fluoxetine. $(N=3-4)$. Data represent means \pm SEM. WT and $5-H T_{\text {Hypo }}$ mice were analyzed separately. (a, b) Two-way repeated-measures ANOVA followed by Bonferroni's post-hoc test. (c, d) Student's t-test. * $p<0.05$. Additional statistical information is available in Supplementary Table SI.

homogenates and found no difference (Supplementary Figure S6). Altogether, our data suggest that 5-HTP is absorbed in the colon as effectively as in the jejunum.

\section{DISCUSSION}

Here we demonstrate, in mice, that adjunct 5-HTP SR augments the pharmacodynamic effect of SSRI treatment in the absence of adverse effects. Adjunct 5-HTP SR strongly and synergistically augmented SSRI-induced $5-\mathrm{HT}_{\text {Ext }}$ elevation. Alone, 5-HTP SR elevated 5-HT $\mathrm{Hxt}_{\mathrm{Ex}}$ only moderately. Potentially, as availability of 5-HTP is the rate-limiting step in 5-HT synthesis (Fernstrom and Wurtman, 1971), adjunct 5-HTP SR leads to greater 5-HT synthesis, vesicular packaging, and release, and when combined with reuptake inhibition by an SSRI, 5-HTP SR results in higher 5-HT $\mathrm{Hxt}_{\mathrm{Ex}}$ levels. The SERT is almost exclusively present on 5-HTergic neurons (Blakely et al, 1991). As the 5- $\mathrm{HT}_{\mathrm{Ext}}$-elevating effect of adjunct 5-HTP SR was much stronger under concomitant SERT-inhibition, likely the delivered 5-HTP was mostly metabolized to 5 -HT within and released by 5 -HTergic neurons.

Good safety is as important as a therapy-like pharmacodynamic effect. We therefore assessed the effect of 5-HTP SR and IR on key physiological, behavioral, and motor function measures. Remarkably, the SR delivery mode expanded the non-toxic 5-HTP dose-range orders of magnitude. Our data indicate that the body adapts well to increased 5-HT metabolism, but tolerates poorly rapid 5-HT fluctuations. The latter was further illustrated by that 5-HTP SR could produce higher non-toxic 5-HTP Plasma levels than 5-HTP IR. The 5-HTP ${ }_{\text {Plasma }}$ levels producing brain $5-\mathrm{HT}_{\mathrm{Ext}}$ augmentation during 5-HTP SR treatment were moderate and similar to levels reported in humans treated chronically with 5-HTP IR (Magnussen and Engbaek, 1978). Although the contrast may be less stark in humans, our mouse data in principle demonstrate the pharmacodynamic and safety superiority of 5-HTP SR over 5-HTP IR.

5 -HTP is effectively absorbed by the human upper intestine (Gijsman et al, 2002), but information on 5-HTP colonic absorption has been lacking. We found that 5-HTP was well absorbed by the mouse colon. The mechanism is unclear. Yet, 5-HTP could undergo active transport by large neutral amino-acid transporters present in the colon as well as in the upper intestine (Broer, 2008).

\section{Advantages and Limitations of our Experimental Approach}

Absent parallel disease models, drug discovery employs pharmacodynamic biomarkers with a rationale for 

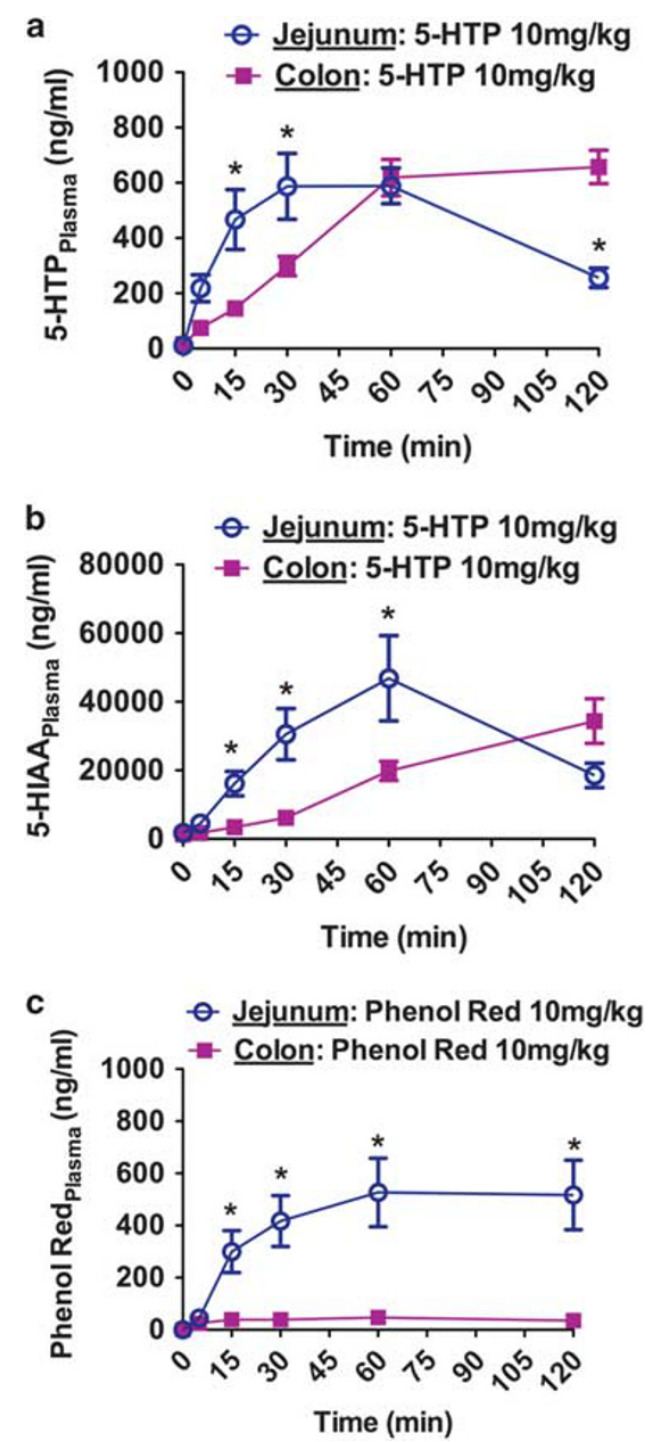

Figure 6 HTP is absorbed by the mouse colon. (a) $5-H T P_{\text {Plasma }}$ and (b) 5-HIAA Plasma levels following injection of 5 -HTP $(10 \mathrm{mg} / \mathrm{kg})$ into the jejunum or colon lumen $(N=8)$. (c) Phenol Redplasma levels following injection of Phenol Red $(10 \mathrm{mg} / \mathrm{kg})$ into the jejunum or colon lumen $(N=6)$. Phenol Red served as a poorly absorbed reference compound. Data represent means \pm SEM. Only WT mice were used. (a-c) Two-way repeated-measures ANOVA followed by Bonferroni's post-hoc test. $* p<0.05$, jejunum vs colon. Additional statistical information is available in Supplementary Table SI.

predictability. Unfortunately, we lack animal behaviors or other pharmacodynamic biomarkers that predict antidepressant action in humans with sufficient fidelity (Insel, 2012). However, multipronged clinical pharmacology data converge on that $5-\mathrm{HT}_{\text {Ext }}$ elevation beyond the SSRI effect equals enhanced antidepressant effect (Ebert et al, 1995; Nardini et al, 1983; Papakostas et al, 2012; van Praag, 1982; Walinder et al, 1976; Whale et al, 2010). For this explicit reason, we optimized our experimental design to specifically address our primary end point-whether adjunct 5-HTP SR can safely elevate $5-\mathrm{HT}_{\mathrm{Ext}}$ beyond the SSRI effect.

Because murine gastrointestinal transit time is $3-4 \mathrm{~h}$ (Nagakura et al, 1996), it is impractical to emulate oral tablet SR delivery in mice. Instead, we modeled SR delivery using subcutaneous osmotic minipumps. Minipumps produce constant SR delivery, independent of dietary intake variations, which is important as the microdialysis procedures (eg, surgery, intubation) can affect food and water intake. The drawbacks are that minipumps are invasive, restricting behavioral toxicology analysis, and that treatment duration $(<7$ days) and dose (max. $100 \mathrm{mg} / \mathrm{kg} /$ day) are limited. Most likely, higher adjunct 5-HTP SR doses can be tolerated and stronger 5- $\mathrm{HT}_{\text {Ext }}$ augmentation achieved, had a higher-capacity rodent SR delivery system been available. Further, 5-HTP SR modeled via 5-HTP in the drinking water increased $5-\mathrm{HT}_{\mathrm{Tissue}}$ as efficiently as minipumps, suggesting that adjunct oral 5-HTP SR can likewise augment SSRIinduced $5-\mathrm{HT}_{\mathrm{Ext}}$ elevation. This is important: a human 5-HTP SR drug would be oral.

Fluoxetine can be administered via the drinking water and is the only SSRI with a long half-life in mice (Holladay et al, 1998); hence, requisite continuous SERT inhibition can be achieved. Our aim was specifically to determine whether 5-HTP SR could elevate 5- $\mathrm{HT}_{\mathrm{Ext}}$ beyond the maximal SSRI effect, not compensate for incomplete SERT inhibition. We therefore used a high dose $(20 \mathrm{mg} / \mathrm{kg} /$ day $)$ of fluoxetine that produces $100 \%$ occupancy and abolition of SERT function. The drawback is that high-dose fluoxetine may bind to targets other than the SERT (Siesser et al, 2013; Werling et al, 2007), which could confound behavioral and molecular analysis, but not $5-\mathrm{HT}_{\mathrm{Ext}}$ assessment.

\section{Adjunct 5-HTP SR as a Future Therapy for TRD}

Integrated with human antidepressant efficacy, 5- $\mathrm{HT}_{\mathrm{Ext}}$ pharmacodynamics, and 5-HTP pharmacokinetics data (Delgado, 2006; Ebert et al, 1995; Gijsman et al, 2002; Lowe et al, 2006; Nardini et al, 1983; Sargent et al, 1998; van Praag, 1982; Walinder et al, 1976; Whale et al, 2010), our mouse data support that 5-HTP's therapeutic potential could markedly improve when delivered as 5-HTP SR. With a 92\% failure rate, CNS drug development is uniquely risky (Kola and Landis, 2004). Arguably, engaging a validated target system (5-HT), using a compound (5-HTP), with a good human safety record, and utilizing a semi-precedented mechanism (elevating $5-\mathrm{HT}_{\mathrm{Ext}}$ beyond the SSRI effect) will increase the probability of a future 5-HTP SR drug to be safe and effective in TRD.

Although not a requirement, colon absorption makes SR formulation easier (Thombre, 2005). As rodent intestinal absorption is reasonably predictive for the human (Bohets et al, 2001), our mouse findings of good colonic absorption of 5-HTP are encouraging. Most rapidly absorbed and eliminated compounds become substantially better drugs in a SR formulation (Thombre, 2005). Certain compoundsincidentally with the same $2 \mathrm{~h}$ half-life as 5-HTP-are only safe and effective in their SR formulations (Brooks et al, 2004; Croom and Wellington, 2006). A SR delivery mode is essential (i) when sustained pharmacodynamic action is required, as for 5-HTergic antidepressants; (ii) when adverse events occur upon dosing, as for 5-HTP; and (iii) when compound half-life is very short, as for 5-HTP.

Depression is highly heterogeneous. No drug will treat all patients. Currently, we cannot predict which patients might respond to adjunct 5-HTP SR. That fluoxetine barely elevated frontal cortex $5-\mathrm{HT}_{\mathrm{Ext}}$ in $5-\mathrm{HT}_{\mathrm{Hypo}}$ mice suggests 
that low endogenous 5-HT levels contribute to SSRI TRD. Indeed, indices of 5-HT deficiency tends to co-segregate with borderline personality disorder, suicidality, and severe depression (Jacobsen et al, 2012a), conditions that when present predict poor SSRI antidepressant response (Kirsch et al, 2008; Leichsenring et al, 2011). Possibly, adjunct 5-HTP SR could have particular therapeutic relevance within such patients.

\section{CONCLUSION}

This study is the first to consider adjunct 5-HTP SR. Yet, the adjunct 5-HTP SR antidepressant rationale can largely be deduced from multipronged published clinical data. Integrated with the previous clinical data, from our mouse data we draw two conclusions: First, a SR formulation will substantially improve the therapeutic properties of 5-HTP. Second, rather than as monotherapy, a 5-HTP SR drug would have its place as an augmentation therapy to SSRIs. Our study was limited to a key pharmacodynamic end point, $5-\mathrm{HT}_{\mathrm{Ext}}$, and to toxicology, and was limited in time, dose, and scope by methodological constraints. Improved modes of modeling 5-HTP SR will enable characterization of the full dose response, behavioral, molecular, and biochemical effects of adjunct 5-HTP SR in animal models. Depression is heterogeneous, making a silver bullet antidepressant implausible. Yet, regardless of mechanisms, and if helping just a subset of TRD patients, any new treatment option could make a substantial positive impact on depression therapy. We posit that the probability that a 5-HTP SR drug will be safe and effective in TRD is above-average. Finally, a 5-HTP SR drug could be relevant for other large SSRI indications, notably generalized anxiety, OCD, PTSD, and social phobia.

\section{FUNDING AND DISCLOSURE}

This work was supported in part by grants from the National Institutes of Health MH79201 and MH60451 (to MGC). Support from the Lennon Family Foundation to MGC for the initial part of this work is also greatly appreciated. BDS is the recipient of a Minority Supplement award from the National Institutes of Health (MH79201-03S1). JPRJ is the grateful recipient of an individual grant from The Lundbeck Foundation of Denmark. JPRJ is inventor on US patent 8969400 pertaining to the adjunct 5-HTP SR method-oftreatment. MGC and JPRJ are inventors on three pending patent application pertaining to the adjunct 5-HTP SR method-of-treatment. MGC and JPRJ hold stock in Evecxia, a company formed to develop a 5-HTP SR drug. MGC has received compensation from Lundbeck as a member of their Psychopharmacology Advisory Board and is a consultant for Omeros Corporation. MGC also owns stock in Acadia Pharmaceutical and has received compensation in the form of honoraria for lecturing at various academic institutions. All other authors declare no conflict of interest.

\section{REFERENCES}

Aan Het Rot M, Zarate CA Jr, Charney DS, Mathew SJ (2012). Ketamine for depression: where do we go from here? Biol Psychiatry 72: 537-547.
Baumann P, Ulrich S, Eckermann G, Gerlach M, Kuss HJ, Laux G et al (2005). The AGNP-TDM Expert Group Consensus Guidelines: focus on therapeutic monitoring of antidepressants. Dialogues Clin Neurosci 7: 231-247.

Beaulieu JM, Zhang X, Rodriguiz RM, Sotnikova TD, Cools MJ, Wetsel WC et al (2008). Role of GSK3 beta in behavioral abnormalities induced by serotonin deficiency. Proc Natl Acad Sci USA 105: 1333-1338.

Bender DA (1983). Biochemistry of tryptophan in health and disease. Mol Aspects Med 6: 101-197.

Benton CS, Miller BH, Skwerer S, Suzuki O, Schultz LE, Cameron MD et al (2012). Evaluating genetic markers and neurobiochemical analytes for fluoxetine response using a panel of mouse inbred strains. Psychopharmacology 221: 297-315.

Berman RM, Cappiello A, Anand A, Oren DA, Heninger GR, Charney DS et al (2000). Antidepressant effects of ketamine in depressed patients. Biol Psychiatry 47: 351-354.

Blakely RD, Berson HE, Fremeau RT Jr, Caron MG, Peek MM, Prince HK et al (1991). Cloning and expression of a functional serotonin transporter from rat brain. Nature 354: 66-70.

Bohets H, Annaert P, Mannens G, Van Beijsterveldt L, Anciaux K, Verboven $\mathrm{P}$ et al (2001). Strategies for absorption screening in drug discovery and development. Curr Top Med Chem 1: 367-383.

Broer S (2008). Amino acid transport across mammalian intestinal and renal epithelia. Physiol Rev 88: 249-286.

Brooks BR, Thisted RA, Appel SH, Bradley WG, Olney RK, Berg JE et al (2004). Treatment of pseudobulbar affect in ALS with dextromethorphan/quinidine: a randomized trial. Neurology 63: 1364-1370.

Celada P, Bortolozzi A, Artigas F (2013). Serotonin 5-HT1A receptors as targets for agents to treat psychiatric disorders: rationale and current status of research. CNS Drugs 27: 703-716.

Collado PS, Munoz ME, Esteller A, Gonzalez J (1988). Phenolsulphonphthalein conjugation and biliary excretion in the rat: influence of phenobarbital and 3-methylcholanthrene. Arch Int Physiol Biochim 96: 17-23.

Croom KF, Wellington K (2006). Modified-release nifedipine: a review of the use of modified-release formulations in the treatment of hypertension and angina pectoris. Drugs 66: 497-528.

Daws LC (2009). Unfaithful neurotransmitter transporters: focus on serotonin uptake and implications for antidepressant efficacy. Pharmacol Ther 121: 89-99.

Delgado PL (2006). Monoamine depletion studies: implications for antidepressant discontinuation syndrome. J Clin Psychiatry 67 (Suppl 4): 22-26.

Ebert D, Albert R, May A, Stosiek I, Kaschka W (1995). Combined SSRI-RIMA treatment in refractory depression. Safety data and efficacy. Psychopharmacology 119: 342-344.

Fernstrom JD, Wurtman RJ (1971). Brain serotonin content: physiological dependence on plasma tryptophan levels. Science 173: 149-152.

Fox MA, Jensen CL, French HT, Stein AR, Huang SJ, Tolliver TJ et al (2008). Neurochemical, behavioral, and physiological effects of pharmacologically enhanced serotonin levels in serotonin transporter (SERT)-deficient mice. Psychopharmacology 201: 203-218.

Gijsman HJ, van Gerven JM, de Kam ML, Schoemaker RC, Pieters MS, Weemaes M et al (2002). Placebo-controlled comparison of three dose-regimens of 5-hydroxytryptophan challenge test in healthy volunteers. J Clin Psychopharmacol 22: 183-189.

Green AR, Aronson JK, Curzon G, Woods HF (1980). Metabolism of an oral tryptophan load. I: Effects of dose and pretreatment with tryptophan. Br J Clin Pharmacol 10: 603-610.

Griebel G, Simiand J, Serradeil-Le Gal C, Wagnon J, Pascal M, Scatton B et al (2002). Anxiolytic- and antidepressant-like effects of the non-peptide vasopressin $\mathrm{V} 1 \mathrm{~b}$ receptor antagonist, 
SSR149415, suggest an innovative approach for the treatment of stress-related disorders. Proc Natl Acad Sci USA 99: 6370-6375.

Griebel G, Stemmelin J, Scatton B (2005). Effects of the cannabinoid $\mathrm{CB} 1$ receptor antagonist rimonabant in models of emotional reactivity in rodents. Biol Psychiatry 57: 261-267.

Hawley CJ, Quick SJ, Ratnam S, Pattinson HA, McPhee S (1996). Safety and tolerability of combined treatment with moclobemide and SSRIs: a systematic study of 50 patients. Int Clin Psychopharmacol 11: 187-191.

Hensler JG (2003). Regulation of 5-HT1A receptor function in brain following agonist or antidepressant administration. Life Sci 72: $1665-1682$.

Hirano K, Seki T, Sakai N, Kato Y, Hashimoto H, Uchida S et al (2005). Effects of continuous administration of paroxetine on ligand binding site and expression of serotonin transporter protein in mouse brain. Brain Res 1053: 154-161.

Holladay JW, Dewey MJ, Yoo SD (1998). Pharmacokinetics and antidepressant activity of fluoxetine in transgenic mice with elevated serum alpha-1-acid glycoprotein levels. Drug Metab Dispos 26: 20-24.

Insel TR (2012). Next-generation treatments for mental disorders. Sci Transl Med 4: 155ps119.

Jacobsen JP, Medvedev IO, Caron MG (2012a). The 5-HT deficiency theory of depression: perspectives from a naturalistic 5-HT deficiency model, the tryptophan hydroxylase 2Arg439His knockin mouse. Philos Trans $R$ Soc Lond B Biol Sci 367: 2444-2459.

Jacobsen JP, Siesser WB, Sachs BD, Peterson S, Cools MJ, Setola V et al (2012b). Deficient serotonin neurotransmission and depression-like serotonin biomarker alterations in tryptophan hydroxylase 2 (Tph2) loss-of-function mice. Mol Psychiatry 17: 694-704.

Kirsch I, Deacon BJ, Huedo-Medina TB, Scoboria A, Moore TJ, Johnson BT (2008). Initial severity and antidepressant benefits: a meta-analysis of data submitted to the Food and Drug Administration. PLoS Med 5: e45.

Kola I, Landis J (2004). Can the pharmaceutical industry reduce attrition rates? Nat Rev Drug Discov 3: 711-715.

Leichsenring F, Leibing E, Kruse J, New AS, Leweke F (2011). Borderline personality disorder. Lancet 377: 74-84.

Lopez-Munoz F, Alamo C (2009). Monoaminergic neurotransmission: the history of the discovery of antidepressants from 1950s until today. Curr Pharm Des 15: 1563-1586.

Lowe SL, Yeo KP, Teng L, Soon DK, Pan A, Wise SD et al (2006). L-5-Hydroxytryptophan augments the neuroendocrine response to a SSRI. Psychoneuroendocrinology 31: 473-484.

Magnussen I, Engbaek F (1978). The effects of aromatic amino acid decarboxylase inhibitors on plasma concentrations of 5-hydroxytryptophan in man. Acta Pharmacol Toxicol (Copenh) 43: $36-42$.

Mischoulon D, Price LH, Carpenter LL, Tyrka AR, Papakostas GI, Baer L et al (2014). A double-blind, randomized, placebo-controlled clinical trial of S-adenosyl-L-methionine (SAMe) versus escitalopram in major depressive disorder. J Clin Psychiatry 75: 370-376.

Nagakura Y, Naitoh Y, Kamato T, Yamano M, Miyata K (1996). Compounds possessing 5-HT3 receptor antagonistic activity inhibit intestinal propulsion in mice. Eur J Pharmacol 311: $67-72$.

Nardini M, De Stefano R, Iannuccelli M, Borghesi R, Battistini N (1983). Treatment of depression with L-5-hydroxytryptophan combined with chlorimipramine, a double-blind study. Int J Clin Pharmacol Res 3: 239-250.

NIMH (2012). FAST: Fast-Fail Trials. NIH, Bethesda, MD, USA (http://www.nimh.nih.gov/research-priorities/research-initiatives/ fast-fast-fail-trials.shtml).

Papakostas GI, Shelton RC, Zajecka JM, Etemad B, Rickels K, Clain A et al (2012). 1-Methylfolate as adjunctive therapy for SSRI-resistant major depression: results of two randomized, double-blind, parallel-sequential trials. Am J Psychiatry 169: 1267-1274.

Perry KW, Fuller RW (1993). Extracellular 5-hydroxytryptamine concentration in rat hypothalamus after administration of fluoxetine plus L-5-hydroxytryptophan. J Pharm Pharmacol 45: 759-761.

Sanchez C, Bergqvist PB, Brennum LT, Gupta S, Hogg S, Larsen A et al (2003). Escitalopram, the S-(+)-enantiomer of citalopram, is a selective serotonin reuptake inhibitor with potent effects in animal models predictive of antidepressant and anxiolytic activities. Psychopharmacology 167: 353-362.

Sargent PA, Williamson DJ, Cowen PJ (1998). Brain 5-HT neurotransmission during paroxetine treatment. The $\mathrm{Br} J$ Psychiatry 172: 49-52.

Sharp T, Boothman L, Raley J, Queree P (2007). Important messages in the 'post': recent discoveries in 5-HT neurone feedback control. Trends Pharmacol Sci 28: 629-636.

Siesser WB, Sachs BD, Ramsey AJ, Sotnikova TD, Beaulieu JM, Zhang X et al (2013). Chronic SSRI treatment exacerbates serotonin deficiency in humanized Tph2 mutant mice. ACS Chem Neurosci 4: 84-88.

Stahl SM (2008). L-methylfolate: a vitamin for your monoamines. J Clin Psychiatry 69: 1352-1353.

Thombre AG (2005). Assessment of the feasibility of oral controlled release in an exploratory development setting. Drug Discov Today 10: $1159-1166$.

Trivedi MH, Rush AJ, Wisniewski SR, Nierenberg AA, Warden D, Ritz L et al (2006). Evaluation of outcomes with citalopram for depression using measurement-based care in $\mathrm{STAR}^{\star} \mathrm{D}$ : implications for clinical practice. Am J Psychiatry 163: $28-40$.

Turner EH, Loftis JM, Blackwell AD (2006). Serotonin a la carte: supplementation with the serotonin precursor 5-hydroxytryptophan. Pharmacol Ther 109: 325-338.

Uutela P, Reinila R, Harju K, Piepponen P, Ketola RA, Kostiainen R (2009). Analysis of intact glucuronides and sulfates of serotonin, dopamine, and their phase I metabolites in rat brain microdialysates by liquid chromatography-tandem mass spectrometry. Anal Chem 81: 8417-8425.

van Praag HM (1982). Serotonin precursors in the treatment of depression. Adv Biochem Psychopharmacol 34: 259-286.

Walinder J, Skott A, Carlsson A, Nagy A, Bjorn-Erik R (1976). Potentiation of the antidepressant action of clomipramine by tryptophan. Arch Gen Psychiatry 33: 1384-1389.

Werling LL, Keller A, Frank JG, Nuwayhid SJ (2007). A comparison of the binding profiles of dextromethorphan, memantine, fluoxetine and amitriptyline: treatment of involuntary emotional expression disorder. Exp Neurol 207: 248-257.

Whale R, Terao T, Cowen P, Freemantle N, Geddes J (2010). Pindolol augmentation of serotonin reuptake inhibitors for the treatment of depressive disorder: a systematic review. J Psychopharmacol 24: 513-520.

Supplementary Information accompanies the paper on the Neuropsychopharmacology website (http://www.nature.com/npp) 